\title{
Hospital transition care for the elderly: an integrative review
}

\author{
Cuidados de transição hospitalar à pessoa idosa: revisão integrativa \\ Cuidados de transición hospitalar a la persona idosa: revisión integrativa
}

\section{Tânia Maria de Oliva Menezes' \\ ORCID: 0000-0001-5819-0570}

Ana Luíza Barreto de Oliveira' ORCID: 0000-0003-3773-6348

Lucivalda Barbosa Santos' ORCID: 0000-0002-6407-2893

Raniele Araújo de Freitas' ORCID: 0000-0002-9367-3639

Larissa Chaves Pedreira'

ORCID: 0000-0001-8939-324X

Sylvia Maria Cardoso Bastos Veras" ORCID: 0000-0002-5326-5235

'Universidade Federal da Bahia. Salvador, Bahia, Brazil. "União Metropolitana de Educação e Cultura. Salvador, Bahia, Brazil.

How to cite this article: Menezes TMO, Oliveira ALB, Santos LB, Freitas RA, Pedreira LC, Veras SMCB. Hospital transition care for the elderly: an integrative review. Rev Bras Enferm. 2019;72(Suppl 2):294-301. doi: http://dx.doi.org/10.1590/0034-7167-2018-0286

\section{Corresponding Author:}

Tânia Maria de Oliva Menezes E-mail: tomenezes50@gmail.com

Submission: 05-07-2018

Approval: 07-31-2018

\section{ABSTRACT}

Objective: to identify evidence of scientific production on hospital transition care provided to the elderly. Method: an integrative review, with publications search in the MEDLINE, PubMed, LILACS, BDENF, Index Psychology and SciELO databases, with keywords and Mesh terms: elderly, hospitalization, patient discharge, health of the elderly, and transitional care, between 2013 and 2017 in English, Portuguese and Spanish. The 14 selected articles analysis was carried out through exploratory and critical reading of titles, abstracts and results of the researches. Results: transitional care can prevent re-hospitalizations as they enable rehabilitation, promotion and cure of illnesses in the elderly. Final considerations: transitional care implies the improvement of the quality of life of the elderly person, requiring skilled health professionals who involve the family through accessible communication. Descriptors: Elderly; Health of the Elderly; Hospitalization; Transitional Care; Patient Discharge.

\section{RESUMO}

Objetivo: identificar evidências da produção científica sobre os cuidados de transição hospitalar prestado à pessoa idosa. Método: revisão integrativa, com busca de publicações nas bases de dados MEDLINE, PubMed, LILACS, BDENF, Index Psicologia e SciELO, com as palavras-chave e Mesh terms: idoso, hospitalização, alta do paciente, saúde do idoso e cuidado transicional, entre 2013 e 2017, nos idiomas inglês, português e espanhol. A análise dos 14 artigos selecionados deu-se por meio da leitura exploratória e crítica dos títulos, resumos e dos resultados das pesquisas. Resultados: os cuidados de transição podem evitar re-hospitalizações, à medida que permitem a reabilitação, promoção e cura de enfermidades na pessoa idosa. Considerações finais: os cuidados transicionais implicam na melhoria da qualidade de vida da pessoa idosa, sendo necessários profissionais de saúde habilitados e que envolvam a família através de comunicação acessível.

Descritores: Idoso; Saúde do Idoso; Hospitalização; Cuidado Transicional; Alta do Paciente.

\section{RESUMEN}

Objetivo: identificar evidencias de la producción científica sobre los cuidados de transición hospitalaria prestados al anciano. Método: una revisión integrativa con búsqueda de publicaciones en las bases de datos MEDLINE, PubMed, LILACS, BDENF, Índice de Psicología y SciELO con palabras clave y Mesh terms: ancianos, hospitalización, alta de los pacientes, la salud y cuidado de personas mayores de transición entre 2013 y 2017, en Inglés, portugués y español. El análisis de los 14 artículos seleccionados se dio por medio de la lectura exploratoria y crítica de los títulos, resúmenes y de los resultados de las encuestas. Resultados: los cuidados de transición pueden evitar re-hospitalizaciones, a medida que permiten la rehabilitación, promoción y cura de enfermedades en lo anciano. Consideraciones finales: los cuidados transicionales implican en la mejora de la calidad de vida de la persona mayor, siendo necesarios profesionales de salud habilitados y que involucran a la famil ia a través de comunicación accesible.

Descriptores: Anciano; Salud del Anciano; Hospitalización; Cuidado de Transición; Alta del Paciente. 


\section{INTRODUCTION}

The number of elderly in Brazil has increased significantly, with the health service of sectors suffering the greatest impact on the change in age structure, since many elderly people are affected by chronic and/or degenerative diseases that when exacerbated can lead to the need for hospitalization.

In Brazil, between 2002 and 2011, there were 20,590,599 hospitalizations of the elderly at SUS (Sistema Único de Saúde Brazilian Unified Health System), accounting for $27.85 \%$ of total hospitalizations and $36.47 \%$ of the funds paid by them ${ }^{(1)}$. The main health affections are associated with chronic diseases and ineffectiveness of health promotion and disease prevention. Such effects can be lowered through the performance of comprehensive public policies, as well as expansion of health promotion, prevention and treatment in a timely and adequate manner to the most diseases incidents in the elderly ${ }^{(2)}$.

In this follow-up, care transition is defined as a set of actions aimed at ensuring continuity of care between transfers of different levels of care or place of transfer ${ }^{(3)}$. In this situation, there may be a change in the functional or health status of the person affected, especially if the person is elderly, in need of preparation for the new situation ${ }^{(4)}$.

Therefore, transitional care should be planned and started throughout hospital, although in practice it is observed that these happen in a timely manner. Authors indicate the importance of this time, it allows the participation of the affected people and their families, helping to adapt to the new environment of care $^{(5-6)}$, while avoiding adverse events and re-hospitalizations ${ }^{(7)}$.

From this perspective, preparation for discharge is configured as a transitional care by advocating continuity of care developed initially in the hospital. This analysis will facilitate the understanding of care for the elderly in their preparation for output, enabling the identification of possible gaps in knowledge about the theme.

\section{OBJECTIVE}

To identify evidence of scientific production on hospital transition care provided to the elderly.

\section{METHOD}

An integrative review of the literature was carried out, a research method that allows the search, critical assessment and synthesis of the available evidence about the subject investigated. Its result is the current state of knowledge on the topic at hand, implementation of effective interventions in health care, cost reduction and identification of gaps that may lead to the development of new research ${ }^{(8)}$.

For this review, six steps have been taken: 1) Establishment of the problem or review of the research question: what are the evidence of the scientific literature on care transition for the elderly? 2) Sampling or search in the scientific literature, applying inclusion and exclusion criteria; 3 ) Categorization of studies, following the previously elaborated reading Protocol, in order to extract the significant data as the object of research for organizing and summarizing information; 4) Assessment of the information obtained, with its critical analysis; 5) Interpretation of the results, discussion and proposals for recommendations; 6) Summary of knowledge or presentation of the review, with summary of the available evidence and details of the review ${ }^{(9)}$.

The literature review is a Evidence-Based Practice (EBP) study, which predicts a methodology to focus on any treatment or through effective diagnosis based on strategies for assessing the quality of studies and mechanisms for the implementation of care, requiring proper construction of the research question and literature search, in particular $\mathrm{PICO}^{(10)}$ strategy. This can be used in the construction of research questions of various types (clinical, human and material resources, etc.) maximizing the recovery of evidence in the databases, emphasizing the scope of research and avoiding unnecessary searches. PICO stands for: Patient, Intervention, Comparison and Outcomes ${ }^{(10)}$.

The chart below describes the strategy used in step 1 , in which the question formulation and search for evidence were guided by the PICO strategy:

Chart 1 - Description of the PICO strategy, 2017

\begin{tabular}{|c|c|l|}
\hline Initials & Description & Analysis \\
\hline $\mathrm{P}$ & Patient & Elderly. \\
\hline I & Intervention & $\begin{array}{l}\text { Care transition continuity and effectiveness } \\
\text { of care of the elderly after hospitalization } \\
\text { process/transfer. }\end{array}$ \\
\hline $\mathrm{C}$ & Comparison & $\begin{array}{l}\text { Consequences of non-transition supply } \\
\text { care for the elderly after hospitalization } \\
\text { and/or transfer to an address. }\end{array}$ \\
\hline $\mathrm{O}$ & Outcomes & $\begin{array}{l}\text { Relevance of transitional care for the } \\
\text { elderly for promotion, rehabilitation and/or } \\
\text { cure in health-disease. }\end{array}$ \\
\hline
\end{tabular}

Using Boolean delimiter operator "AND" was chosen in order to restrict transitional care findings provided to the hospitalized elderly.

In step 2, the following inclusion criteria were established: articles published in peer-reviewed journals on highlighted aspects of transitional care for the elderly; full text in English, Portuguese and Spanish, available for free; publications between 2013 and 2017, considering that the subject is recent and still not implemented in the Brazilian reality.

In addition to the inclusion criteria mentioned above, in the process of selection and assessment of the methodological quality of the studies, the classification was used for the level of scientific evidence ${ }^{(11)}$. The exclusion criteria were repeated articles being considered only once; monographs, dissertations, theses; review articles and reflection. Figure 1 shows the flowchart in the search databases and the selection process and inclusion of articles:

To step 3, in January 2018 searches were carried out in the databases: Scientific Electronic Library Online - SciELO; Virtual Health Library bases (VHL): Medical Literature Analysis and Retrieval System Online (MEDLINE), Latin American and Caribbean Health Sciences - LILACS, Nursing Database (BDENF - Banco de Dados em Enfermagem), Index Psychology by using the following VHL's Health Science Descriptors (DECS - Descritores de Ciências em Saúde) and the National Library's Medical Subject Headings (MeSH) to knowledge of universal descriptors:"Idoso/Aged" AND "Hospitalização/Hospitalization" AND "Alta do Paciente/Patient 


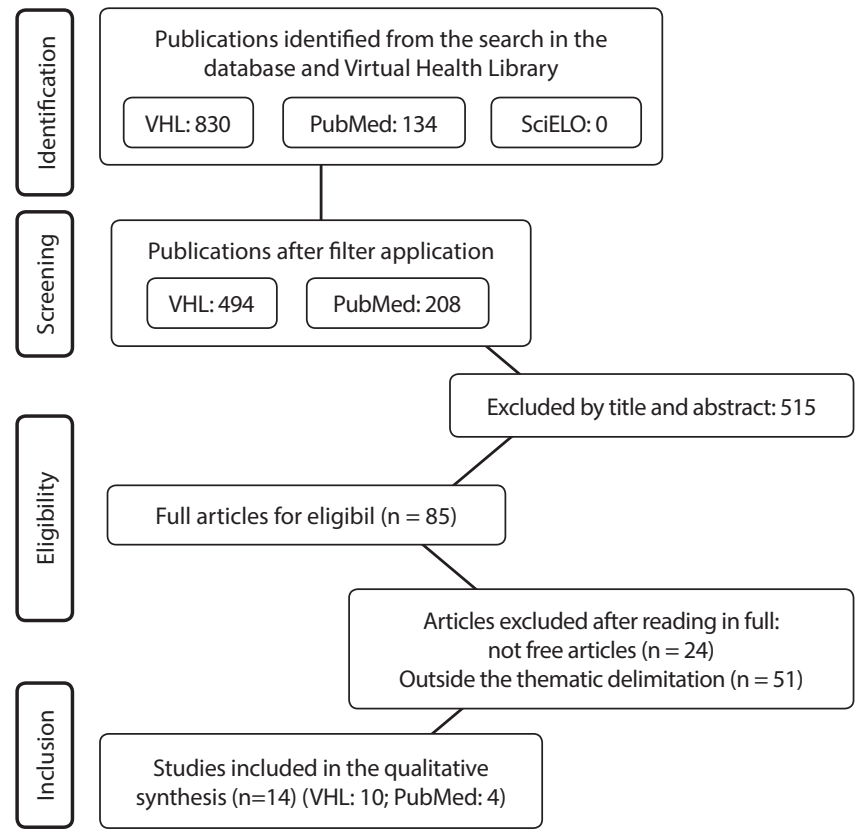

Figure 1 - search flowchart in the PubMed, Lilacs, MEDLINE, Index Psychology, SciELO databases, 2018

Discharge", "Saúde do Idoso/Healthy of the Elderly" and "Cuidado Transicional/Transitional Care", which were combined in different ways to ensure a broad search.

By using the English descriptors through the Boolean operator "AND" in the SciELO database, no articles on the topic were found. In the selected VHL databases, 1,456 articles were found. Applying the inclusion/exclusion criteria, 494 articles remained. After reading the titles and abstracts, 73 eligible articles were selected. Of these, 24 articles had access costs and 39 had no adherence to the study, being selected ten articles for the analysis.

When performing search in PubMed database, initially 1,602 articles were selected. By applying the inclusion and exclusion criteria, 208 articles were selected. After reading the title and abstract, 12 articles were identified. After reading in full, four articles were selected with adherence to the object of study.

In order to favor the validation of the selection of publications, the potentially elected articles were assessed by three reviewers independently using the inclusion and exclusion criteria mentioned above and guided by the research question. Using a JBI QARI Critical Appraisal Checklist for Interpretive \& Critical Research ${ }^{(9)}$, each reviewer recorded their assessment and justification for inclusion or exclusion of the article on a form that respective titles, abstracts and database.

Results were compared and disagreements were resolved by agreement of the expert reviewer. This final sample selection of the validation process of the publications allowed the inclusion of surveys presented consistency and contribute to achieving the objective. At the end, 14 studies remained.

For the collection and analysis of data that make up the phase 4 , was developed an instrument that consisted of: Journal title, level of evidence, publication year, country, language of publication, study site, professional category of the article's authors, Qualis of the journal and main results, as the object of study. Steps 5 and 6 corresponding to the analysis of the studies included in the review, the interpretation of the results and the presentation of the review follow in the results and discussion of this article.

Data analysis occurred in two moments: in the first, the reading, data description and construction of synoptic tables were performed; and in the second moment, the data were grouped by similarities, organized and compared, pointing out similarities and differences. Presentation of results and analysis of data was taken in a descriptive manner, with the synthesis of each article.

\section{RESULTS}

Chart 2 shows that, in the year of publication of the articles, the highlight was in 2015, with six articles (42.8\%), followed by 2014 , with three articles (21.4\%). The year of least publication was 2012 , with one article (7.1\%). This finding indicates that the subject is recent, presented in increasing discussion and is being further addressed in foreign countries, publishing predominantly in English, with 13 (90\%) items and only one (10\%) in Portuguese.

As for the country with the highest number of publications, the United States stands out with four (28.6\%), followed by Canada, with three (21.4\%), highlighting North America as the center of interest.

The Qualis Nursing of the selected journals were $A 1$ and $B 1,5$ (35.7\%) each, followed by A2, 3 (21.4\%), showing publication in relevant journals. The only study published in the national journal was not in an expressive Qualis, which demonstrates the need to broaden the research on the subject in our country, divulging in the various journals.

Regarding publication language, 13 (92.8\%) articles were published in English. Only one (7.1\%) in Portuguese, conducted in Brazil, demonstrating the lack of studies on the subject in the country.

Regarding the professional category, studies on transition care for the elderly are published by nurses and other health professionals in medical journals corresponding to $13(92.8 \%)$ articles selected for the study with a specific approach in Geriatrics. Nevertheless, there were also approach this theme in Psychology. However, in only one (7.2\%) of the articles, stressing that transitional care also runs through an interdisciplinary approach suggesting that other professional categories seek to research on the subject in order to attend to the comprehensive dimension of being by qualifying care.

Chart 3 presents the objectives of the studies and the syntheses of the ideas seized by the articles selected in this review. The results indicate that, in preparing the hospitalized elderly person and their relatives for home adaptation after hospital discharge, the reduction of costs and re-hospitalization rates.

\section{DISCUSSION}

The elderly, when hospitalized, becomes a major challenge for the health team, due to the complexity of care actions to be performed and the vulnerability existing during hospitalization and after discharge ${ }^{(12)}$. Therefore, the effectiveness of the multidisciplinary approach, the optimization of medical care and the early review in the post-discharge period reduce the use of care in hospital institutions ${ }^{(13)}$, leading to a reduction in hospitalization costs. 
Chart 2 - Characterization of items that made up the analysis corpus, 2017

\begin{tabular}{|c|c|c|}
\hline Reference (Year) & Study location (Country/Language) & Journal title (Qualis) \\
\hline$A^{5}(2014)$ & Public hospital in the Federal District (Brazil/Portuguese) & Estudos de Psicologia (B4) \\
\hline$A^{12}(2015)$ & Vlietland Hospital (Netherlands/English) & BMC Health Serv Res (A2) \\
\hline$A^{13}(2013)$ & University of Queensland School of Medicine (Australia/English) & European Journal of Internal Medicine (B1) \\
\hline$A^{14}(2015)$ & University of Alberta and Royal Alexandra Hospital (Canada/English) & Canadian Medical Association Journal (A1) \\
\hline$A^{15}(2016)$ & Nine geriatric units of the Rhône-Alpes region of France (France/English) & BMC Geriatrics (B1) \\
\hline$A^{16}(2012)$ & William S. Middleton Memorial Veterans Hospital (US/English) & Health Affairs (A1) \\
\hline$A^{17}(2015)$ & Singapore General Hospital (Singapore/English) & Health Res BMC Ser (A2) \\
\hline$A^{18}(2014)$ & Community teaching hospital in the Northeast US (US/English) & Journal of the American Geriatrics Society (A1) \\
\hline$A^{19}(2016)$ & $\begin{array}{l}\text { Nursing facilities in five states using Centers for Medicare and Medicaid } \\
\text { Service (Canada/English) }\end{array}$ & Annals of Surgery (B1) \\
\hline$A^{20}(2013)$ & Madison VA Hospital (US/English) & $\begin{array}{l}\text { International Journal of Qualitative Studies on } \\
\text { Health and Well-being (A1) }\end{array}$ \\
\hline$A^{21}(2015)$ & Western Hospital - Australia - medical assessment unit (Australia/English) & BMC Geriatrics (B1) \\
\hline$A^{22}(2015)$ & San Francisco General Hospital and Trauma Center (SFGH) (US/English) & Journal of General Medicine Interm (TO 1) \\
\hline$A^{23}(2015)$ & Intermediate Care Hospital (ICH) (Norway/English) & BMC Health Serv Res (A2) \\
\hline$A^{24}(2014)$ & Community Care Access Center (CCAC) (Canada/English) & European Journal of Internal Medic (B1) \\
\hline
\end{tabular}

Chart 3 - Main results and recommendations of the selected articles, 2018

\begin{tabular}{|c|c|c|}
\hline Reference & Objective & Results and recommendations of the transitional care \\
\hline A5 & $\begin{array}{l}\text { To assess feasibility and results of the intervention focused } \\
\text { on the family to promote functional recovery of the } \\
\text { hospitalized person. }\end{array}$ & $\begin{array}{l}\text { Involvement of patients, family members and nursing staff in the } \\
\text { promotion of transitional care in hospitalized elderly, providing for safe } \\
\text { hospital discharge, avoids re-hospitalizations. }\end{array}$ \\
\hline A12 & $\begin{array}{l}\text { To identify the longitudinal relationship between experiences } \\
\text { of elderly patients with hospital care, perceived quality } \\
\text { integrated care and quality of life after hospitalization. }\end{array}$ & $\begin{array}{l}\text { Transitional care with integrated care for elderly patients directly } \\
\text { interfere with their quality of life after hospital discharge. }\end{array}$ \\
\hline A13 & $\begin{array}{l}\text { To describe the quality of the transition in elderly patients } \\
\text { frequently admitted. }\end{array}$ & $\begin{array}{l}\text { Opportunities for better education of the patient and the caregiver can } \\
\text { increase adherence to the transitional care provided to high-risk elderly. }\end{array}$ \\
\hline A14 & $\begin{array}{l}\text { To assess the impact of weakness in re-hospitalization or } \\
\text { death within } 30 \text { days after discharge from the intensive } \\
\text { care units. }\end{array}$ & $\begin{array}{l}\text { Transitional care can be incorporated reducing tensions and risks of re- } \\
\text { hospitalizations, especially for those who have had prolonged periods of } \\
\text { bed rest. }\end{array}$ \\
\hline A15 & $\begin{array}{l}\text { To assess the impact of a transitional care program from } \\
\text { one hospital to another, for seniors admitted to short } \\
\text { drives. }\end{array}$ & $\begin{array}{l}\text { Low quality of transitional care can result in medication errors, } \\
\text { discontinuity of care plans, dissatisfaction for elderly patients and } \\
\text { consequently re-hospitalizations. }\end{array}$ \\
\hline A16 & $\begin{array}{l}\text { To assess the Transitional Care Coordination Program } \\
\text { (C-TraC) used in a hospital in Madison. }\end{array}$ & $\begin{array}{l}\text { The implementation of a viable program of transition care which reduces } \\
\text { re-hospitalizations (C-TraC -based phone) provides a cost-effective } \\
\text { transition of care. }\end{array}$ \\
\hline A17 & $\begin{array}{l}\text { To assess whether a transitional care program operated by } \\
\text { the Singapore General Hospital was effective in reducing } \\
\text { the use of emergency room visits and hospitalizations. }\end{array}$ & $\begin{array}{l}\text { Patients who undergo the transition to home care have significantly } \\
\text { lower emergency room visits and hospitalizations. }\end{array}$ \\
\hline A18 & $\begin{array}{l}\text { To know and analyze the perception of the elderly on } \\
\text { hospital discharge, defined as hospital-home transition. }\end{array}$ & $\begin{array}{l}\text { It is important to have planning and coordination of the transitional care } \\
\text { and discharge to ensure the continuity of comprehensive care to the elderly. }\end{array}$ \\
\hline A19 & $\begin{array}{l}\text { To assess elderly patients who left specialist care and to } \\
\text { identify risk factors for not returning home and death, } \\
\text { and development of a tool to determine the likelihood of } \\
\text { adverse outcomes. }\end{array}$ & $\begin{array}{l}\text { A better understanding of hospitalization and risk factors for non- } \\
\text { return of the home, re-hospitalization and death should help identify } \\
\text { intervention opportunities to improve the outcome. }\end{array}$ \\
\hline A20 & $\begin{array}{l}\text { To explore family experiences in the hospital when an } \\
\text { elderly patient is discharged to home care in order to } \\
\text { identify issues that may facilitate the participation of } \\
\text { relatives in } m \text { more efficient environment. }\end{array}$ & $\begin{array}{l}\text { Aiming to positive results in the transition of care, the health team needs } \\
\text { to develop more communication skills and collaboration to guide the } \\
\text { family involved in the transition of care. }\end{array}$ \\
\hline A21 & $\begin{array}{l}\text { To investigate a new approach to identify and address the } \\
\text { needs of family caregivers after discharge of the elderly } \\
\text { receiving care. }\end{array}$ & $\begin{array}{l}\text { For effective implementation of transitional care should identify and } \\
\text { address the needs of family caregivers after discharge of the elderly } \\
\text { receiving such care. }\end{array}$ \\
\hline A 22 & $\begin{array}{l}\text { To assess the effect of a transition from hospital care } \\
\text { intervention conducted by nurses on the patient's } \\
\text { experience related to hospital in a multilingual population } \\
\text { of hospitalized elderly. }\end{array}$ & $\begin{array}{l}\text { Transitional care projects for the elderly, including nursing's role in the } \\
\text { sense of direction, safely, ensure improvement in health and experiences } \\
\text { of elderly in the post-discharge. }\end{array}$ \\
\hline
\end{tabular}




\begin{tabular}{|c|l|l|}
\hline Reference & Objective & Results and recommendations of the transitional care \\
\hline A23 & $\begin{array}{l}\text { To compare the use of health services by the elderly in a } \\
\text { municipality with the transition of care for elderly patients } \\
\text { in a county without such care. }\end{array}$ & $\begin{array}{l}\text { Years after the introduction of transitional care, length of hospital } \\
\text { stay for patients aged } 60 \text { or more was reduced considerably without } \\
\text { increasing the number of hospitalizations or re-hospitalizations. }\end{array}$ \\
\hline A24 & $\begin{array}{l}\text { To assess whether there is an association between the } \\
\text { presence of caregivers and the realization of transitional } \\
\text { care. }\end{array}$ & $\begin{array}{l}\text { The six properties that characterize the needs of transitional care are: } \\
\text { assessment of single family situation; practical information, education } \\
\text { and training; participation in the planning process; agreement between } \\
\text { formal and informal caregivers; time to make changes in their personal } \\
\text { lives; and emotional preparation. }\end{array}$ \\
\hline
\end{tabular}

In this respect, an article suggests the implementation of a telephone program to solve possible problems at home. The implementation of a viable transitional care program that reduces re-hospitalizations (C-TraC-based, on the telephone) presents satisfactory results, operating at a relatively low cost and encompassing other settings challenged by geographic distance, limited resources or patients who the visits to the study care team $^{(14)}$ are rejected, which can contribute to a low cost of care, reducing the constant need for the hospital service.

A research in France indicated that $14 \%$ of the elderly aged 75 years or more were hospitalized 30 days after hospital discharge for preventable reasons. Among these reasons, some are related to the clinical status of patient, such as comorbidities, musculoskeletal disorders and others; to their home environment and support network. Nevertheless, the deficiency of the health system in managing the transition from hospital to home care is the main factor for the return of this elderly to the hospital environment ${ }^{(15)}$.

It is also necessary to identify the risk factors that allow the elderly to return to the hospital environment ${ }^{(16)}$, because rejection of continuity of treatment, absence of post-discharge consultations, indiscriminate use of medications, re-hospitalizations, and death may be the result of negative experiences of the elderly during hospitalization and unaccompanied behaviors ${ }^{(17)}$.

Studies show the importance of transitional care in the process of rehabilitation, rehabilitation, intervention, promotion and even cure of the elderly during discharge to the destination of origin ${ }^{(5,18)}$, implying significantly the lower re-hospitalizations of these individuals ${ }^{(12,15,19)}$.

Transitional care begins at the time of hospitalization, continues during hospitalization and remains after discharge, as the perception about the quality of life will be totally re-signified from this experience ${ }^{(13)}$. On the other hand, hospital environments deal only with biological aspects, not being designed clinically and operationally to support and help elderly people to recover or improve functionality and return to their activities after the period of hospitalization ${ }^{(16)}$.

Effective intervention for the transition from hospital to home care is intended to maintain continuity of care and reduce the occurrence of complications. The actions must take place in three distinct stages: starting before patient leaves the hospital, at the time of hospital discharge, and finally, within 48 hours and up to 30 days after discharge ${ }^{(13)}$.

Hospital discharge is a specific transition that provides for the continuity of home care, and when failures occur in the planning and performance stages of discharge, leads to infer that the professional is discharging patient, transferring the hospital care, that is, returning the patient to the hospital. family and excluding the hospital institution from its responsibility ${ }^{(5)}$.
In this context, transition care delivery planning is a practice that must be developed within the hospital environment, used as a care strategy, in which the elderly is at the center of this process. This type of approach increases the quality of care provided, since it provides activities and information according to the patient's need and, above all, preserves their individuality and integrity ${ }^{(17)}$.

Many of the re-hospitalizations of the elderly population are due to poor communication between the health care team and the family regarding post-discharge guidelines and care, as well as the planning of this, including drug reconciliation. Therefore, it is necessary to identify interventions and facilitating factors for the performance of transitional care, aiming at the success of hospital discharge, thus avoiding the re-hospitalization of these persons ${ }^{(18)}$.

Implementation of transitional care requires medical professional and nurse since the hospitalization, stay and discharge of the elderly from the hospital environment. During hospitalization, a discharge plan is drawn up, with the proposal of assessing patient in his real clinical conditions, obtaining information about the support networks existing outside the hospital, as well as providing patient and family guidance, with attention especially for the use of drugs, appointment scheduling and clinical monitoring ${ }^{(13)}$.

Successful interventions include education on patient discharge, drug reconciliation, improved communication with health professionals, and pre-discharge outpatient follow-up ${ }^{(16)}$, as well as developing more elaborate and relevant interventions to adequately support patients and their patients during transitional care. It is believed that there is a need for health professionals to work closely with family members to identify and address the needs of the health care user during the transition from the hospital to the home $\mathrm{e}^{(4)}$.

For the success of transitional care, the participation of the family member during the development of the recommended post-discharge activities for the continuity of care in the home is highlighted, in order to improve the quality of care provided and thus the state of health of the elderly.

Concurrently, the hospital/household transition was identified as a time of stress for family members who assume the role of caregiver. Stress is often precipitated by lack of necessary skills, knowledge and tools for effective care ${ }^{(4,13)}$.

Regarding the family's experiences with the health professional at the time the elderly is discharged, in order to identify aspects that may facilitate taking care of in an efficient way, the relatives point out feelings of negligence on the part of the professionals and the hospital institution, as well as such as the absence of clear routines involving them in the context of leaving home. This left them confused, insecure and concerned about the future care of the elderly patient ${ }^{(20)}$. 
Thus, family caregiver in the provision of transition care for the elderly should be assessed with great caution, since several factors are involved, such as kinship level, schooling, age, sex, occupation, residence, degree of approximation with the patient, how long have they been taking care of himself and health. All these aspects will be articulated and used at the time of discharge planning, as they will support the necessary guidelines for the caregiver(21).

When the health professional cannot adjust the vocabulary during the planning of the discharge of the patient with skills and knowledge of family members, it makes it difficult to understand the information, leading to misunderstanding. Furthermore, insecurity about the health status of the elderly and routines that should be followed after discharge, causing that the transition from the institution to the home does not function as it should ${ }^{(19)}$. Therefore, it is necessary that in this process the caregiver be guided in such a way to take over, manage and sustain this activity ${ }^{(4,21)}$.

In this perspective, the role of the nurse in the use of a care plan as the main intervention directed to the patient and the family at the time of hospital discharge is highlighted. Through an effective, clear, objective and enlightening communication, it should motivate the elderly and the caregiver to take over a more active role in this process. Guidelines are offered so that there is compression, so that the maintenance of care remains independent of the setting that occurs ${ }^{(13)}$.

Furthermore, during planning and performance of transitional care, effective communication between the elderly/family and the health professional is essential, so that failures in this stage do not result in re-hospitalizations. Efficient communication is based on planning, which aims at continuing education for the elderly and their family in the context of treatment, maintenance of medication and guidance of support networks, allowing a better experience after discharge, reducing the burden at home ${ }^{(22)}$.

The impact of the programs that involve nursing actions in the prevention of hospital re-hospitalization reflects the importance of the nurse in this type of care, since it is inserted in the whole process of the intervention acting directly from the hospitalization of the elderly to the exit to the home, information on the clinical history, family network, discharge conditions, home environment, medication use, scheduling of consultations and assistance through the primary network, guiding their caregiver on how their daily routine should be organized ${ }^{(13)}$.

Nursing care as the main object of the nurse's practice begins in an objective way, with an educational action on consultations and follow-ups, to maintain the treatment and guidance regarding the use of medications that will often be the same as in the hospital environment, as well as to alert about the appearance of signs and symptoms that represent health risk and the need to return to the hospital environment. It is also up to the professional to work through home visits two weeks after leaving. This type of care assesses the impact of adequate planning on discharge ${ }^{(22)}$.

The nurse plays an important role in the intervention process during the development of transitional care because of the proximity to the patient. This allows the formation of a greater bond and a better effectiveness in communication, resulting in positive aspects in the health of the elderly.

The use of strategies brings favorable results, when they minimize the consequences of the activities of daily life of the elderly at the time of hospital discharge. Transitional care is also seen as an intermediary health practice, and can act as an extension of the referral hospital, with a community focus on the prevention of unnecessary hospitalization. Patients with family caregivers are more than five times more successful with transitional care than patients with formal caregivers ${ }^{(23)}$.

Communication between health professionals, patients and family members at hospital discharge is associated with better health outcomes and lower costs. For these and other reasons, quality improvement agencies promote the inclusion of family caregivers in the health-patient-hospitalization team, already

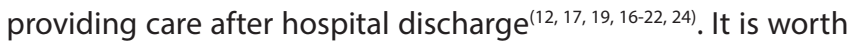
emphasizing that with the insertion of family members, they are subject to stress and other symptoms, and therefore measures must be taken to assess the caregiver's tension, while establishing a partnership with the team that initiates care transition ${ }^{(24)}$.

Improving communication and patient involvement in transitional care is essential, since misunderstanding of discharge instructions increases the risk of re-hospitalization. Therefore, the quality of communication between family members and health professionals needs to receive greater attention from educational institutions and health organizations, as there is a need for communication skills among professionals, including information, respect and collaboration on the part of these professionals ${ }^{(18)}$.

Health service guidelines, review period, transportation locations for scheduled appointments are some of the strategies that enable follow-up services for the elderly, when necessary ${ }^{(22)}$. The use of an instrument to identify risk factors that make it possible to return to the hospital environment also constitutes an important tool in the assessment of transition care, since it makes it possible to assess the actual conditions of discharge or risk of re-hospitalization ${ }^{(12)}$.

Support for transitional care is also focused on drug administration, since older people need to know the drugs that will be used. Therefore, how much to the side effects and to the proper administration of the same ones. As a practice of this kind of care, it is the provision of contact numbers and instructions in emergency situations. Other strategies in transition care are the use of explanatory leaflets, follow-up after discharge, motivational interview, and positive self-care behavior promotion ${ }^{(14)}$.

Nevertheless, patient experience is an important component in delivering quality care. The result of this successful experience is an elderly person who has good adherence to treatment ${ }^{(22)}$. Thus, interventions are aimed at the promotion, maintenance or restoration of health. This practice can be used to intermediate the support of the local networks of the health services, as well as to maintain the follow-up of the consultations and actions established during hospital discharge ${ }^{(15)}$.

The results indicate that transition care is beneficial for elderly people with multiple complex chronic and therapeutic conditions, as well as for their family members and/or caregivers, who often become vulnerable to disarrangement or lack of care due to lack of guidance.

In this way, the transition from the hospital to the home, be it institutional or residential, exerts on health professionals, in particular the nurse, family and health institution, the co-responsibility of support for adherence and the good development of 
transition care for the elderly. Furthermore, an effective network is needed, through trained and integrated professionals with discharge planning, in order to improve the quality of life of this population segment. Thus, re-hospitalizations and the increase in the mortality rate due to the ineffectiveness of care in question would be avoided.

\section{Study limitations}

The limitation of this study is the exclusion of 24 articles that were available for payment.

\section{Contributions to Nursing, Health and Public Policy}

The results point to the need for more interventions by health professionals in transition care for the elderly, involving patient and family. The nurse stands out as the coordinator of the planning for the transfer of care to be performed in the extra-hospital environment, thus favoring the clear understanding among those involved in the therapeutic process through secure communication, constantly monitoring their effectiveness and encouraging health promotion. Scientific evidence provides means for the planning of public health policies for this population group, since the implementation of the process of transition of care in a systematized way contributes to its continuity, avoiding errors or absence of the necessary care for the elderly when transiting from the hospital for the home.

\section{FINAL CONSIDERATIONS}

Scientific production analysis showed that transition care for the elderly is necessary, as they reduce new hospitalizations and optimize the health-disease process. It emphasizes the need for professional qualification for planning and directing transition care, effective communication between professional/elderly/ caregiver, as well as being indispensable to insert the caregiver/ family in this context in a formal and participatory manner.

A small number of national studies were observed in the sample of this review, indicating the need for new studies in the field of Gerontology and Geriatrics related to transitional care as a strategy for therapeutic efficacy and, in particular, with regard to the practice of nurses.

\section{REFERENCES}

1. Izaias EM, Dellaroza MSG, Rossaneis MA, Belei RA. Custo e caracterização de infecção hospitalar em idosos. Rev Ciênc Saúde Coletiva [Internet]. 2014 [cited 2017 May 05];19(8):3395-402. Available from: http://www.scielo.br/pdf/csc/v19n8/1413-8123-csc-19-08-03395.pdf

2. Silveira RE, Santos AS, Sousa MC, Monteiro TS. Expenses related to hospital admissions for the elderly in Brazil: perspectives of a decade. Einstein [Internet]. 2013 [cited 2017 Mar 23];11(4):514-20. Available from: http://www.scielo.br/pdf/eins/v11n4/en_19.pdf

3. Oakes SL, Gillespie SM, Ye Y, Finley M, Russell M, Patel NK, et al. Transition al care of the long-term care patient. Clin Geriatr Med [Internet]. 2011 [cited 2017 Apr 17];27(2):259. Avaliable from: http://www.geriatric.theclinics.com/article/S0749-0690(11)00013-9/fulltext

4. Giosa JL, Stolee P, Dupuis SL, Mock SE, Santi SM. An examination of family care giver experiences during care transitions of older adults. Canadian J [Internet]. 2014 [cited 2017 Mar 27];137-53. Available from: https:// www.cambridge.org/core/journals/canadian-journal-on-aging-la-revue-canadienne-du-vieillissement/article/ an-examination-of-family-caregiver-experiences-during-care-transitions-of-older-adults/F5CF2C5A440B22B630B2E953E3433276

5. Flesch DL, Araújo TCCF. Alta hospitalar de pacientes idosos: necessidades e desafios do cuidado contínuo. Estud Psicol[Internet]. 2014 [cited 2017 Mar 23];19(3):157-238. Available from: http://www.scielo.br/pdf/epsic/v19n3/08.pdf

6. Foss C, Hofoss D. Patient Education and Counseling Elderly persons' experiences of participation in hospital discharge process. Patient Educ Couns [Internet]. 2011 [cited 2017 Jan 16];85(1):68-73. Available from: https://www.ncbi.nlm.nih.gov/pubmed/20884160

7. Hung D, Leidig RC. Implementing a Transitional Care Program to Reduce Hospital Readmissions Among Older Adults. J Nurs Care Qual [Internet]. 2015 [cited 2017 Jan 16];30(2):121-9. Available from: https://onlinelibrary.wiley.com/doi/full/10.1111/j.1945-1474.2011.00167.x

8. Mendes KDS, Silveira RCCP, Galvão CMM. Revisão Integrativa: método de pesquisa para a incorporação de evidências na saúde e na enfermagem. Texto Contexto Enferm[Internet]. 2008 [cited 2017 Apr 13];17(4):758-64. Available from: http://www.scielo.br/pdf/tce/v17n4/18.pdf

9. The Joanna Briggs Institute. Reviewers' manual[Internet]. Adelaide/Austrália: The Joanna Briggs Institute. 2014 [cited 2018 Feb 10]. Available from: https://joannabriggs.org/assets/docs/sumari/ReviewersManual-Methodology-JBI_Umbrella\%20Reviews-2014.pdf

10. Santos CMC, Pimenta CAM, Nobre MRC. The PICo strategy for the research question construction and evidence search. Rev Latino-am Enfermagem [Internet]. 2007 [cited 2017 Nov 14];15(3):508-11. Available from: http://www.scielo.br/pdf/rlae/v15n3/v15n3a23.pdf

11. Stillwell SB, Fineout-Overholt E, Melnyk BM. Evidence-based practice step by step. Am J Nurs [Internet]. 2010 [cited 2018 Feb 17];110(5):417. Available from: http://download.lww.com/wolterskluwer_vit.alstream_com/PermaLink/NCNJ/A/NCNJ_546_156_2010_08_23_ SADFJO_165_SDC216.pdf

12. Kahlon S, Pederson J, Majumdar SR, Belga S, Lau D, Fradette M, et al. Association between frailty and 30-day outcomes after discharge from hospital. Canadian Med Assoc J [Internet]. 2015 [cited 2017 Apr 17];187(11):799-804. Available from: https://www.ncbi.nlm.nih.gov/pmc/ articles/PMC4527901/

13. Occelli P, Touzet S, Rabilloud M, Ganne C, Poupon Bourdy S, Galamand B, et al. Impact of a transition nurse program on the prevention of thirty-day hospital readmissions of elderly patients discharged from short-stayunits: study protocol of the PROUST stepped-wedge cluster 
randomized trial. BMC Geriatr[Internet]. 2016 [cited 2017 Mar 23];16(1):57. Available from: https://www.ncbi.nlm.nih.gov/pmc/articles/ PMC4776355/

14. Kind AJH, Jensen L, Barczi S, Bridges A, Kordahl B, Smith, MA, et al. Low-Cost Transitional care with nurse managers making mostly phone contact with patients cut rehospitalization at a VA Hospital. Health affairs (Project Hope) [Internet]. 2012 [cited 2017 May 17];31(12):2659-68. Available from: https://www.ncbi.nlm.nih.gov/pmc/articles/PMC3520606/

15. Low LL, Vasanwala FF, NG LB, Chen C, Lee KH, Tan SY. Effectiveness of a transitional home care program in reducingacute hospital utilization: a quasi-experimental study. BMC Health Services Research [Internet]. 2015 [cited 2017 May 03];15:100. Available from: http:// bmchealthservres.biomedcentral.com/articles/10.1186/s12913-015-0750-2

16. Mudge AM, Shakhovskoy R, Karrasch A. Quality of transitions in older medical patients with frequente readmissions: opportunities for improvement. Eur J Intern Med. [Internet]. 2013[cited 2017 May 03];24(8):779-83. Available from: http://www.sciencedirect.com/science/ article/pii/S0953620513009175

17. Hartgerink JM, Cramm JM, Bakker TJ, Mackenbach P, Niebor AP. The importance of older patients' experiences with care delivery for their quality of life after hospitalization. BMC Health Serv Res[Internet]. 2015 [cited 2017 May 04];15(1):1. Available from: http://bmchealthservres. biomedcentral.com/articles/10.1186/s12913-015-0982-1

18. Hakkarainen TW, Arbabi S, Willis MM, Davidson GH, Flum DR. Outcomes of patients discharged to skilled nursing facilities after acute care hospitalizations. Ann Surg [Internet]. 2016 [cited 2017 May 05];263(2):280-85. Available from: https://www.ncbi.nlm.nih.gov/pmc/articles/ PMC4706779/

19. Boltz M, Resnick B, Chippendale T, Galvin J. Testing a family-centered intervention to promote functional and cognitive recovery in hospitalized older adults. J Am Geriatr Soc [Internet]. 2014 [cited 2017 Apr 20];62(12):2398-407:228. Available from: https://www.ncbi.nlm. nih.gov/pmc/articles/PMC4883662/

20. Pennbrant S. A trustful relationship: the importance for relatives to actively participate in the meeting with the physician. Int J Qualit Stud Health Well-being [Internet]. 2013 [cited 2017 May 05];8:10.3402/qhw.v8i0.20608. Available from: https://www.ncbi.nlm.nih.gov/pmc/ articles/PMC3660621/

21. Toye C, Moorin R, Slatyer S, Aoun SM, Parsons R, Hegney D, et al. Protocol for a randomised controlled trial of an outreach support program for Family carers of older people discharged from hospital. BMC Geriatr [Internet]. 2015 [cited 2017 May 04];15:1-7. Available from: https:// www.ncbi.nlm.nih.gov/pmc/articles/PMC4479237/

22. Chan B, Goldman LE, Sarkar U, Schneidermann M, Kessell E, Guzman D, et al. The effect of a care transition intervention on the patient experience of older multi-lingual adults in the safety net: results of a randomized controlled trial. J Gen Internal Med [Internet]. 2015 [cited 2017 Mar 27];1788-94. Available from: https://www.ncbi.nlm.nih.gov/pmc/articles/PMC4636586/

23. Epstein-Lubow G, Baier RR, Butterfield K, Gardner R, Babalola E, Coleman EA, et al. Caregiver presence and patient completion of a transitional care intervention. Am J Managed Care [Internet]. 2014 [cited 2017 May 05];20(10):e349-444. Available from: http:// caretransitions.org/wp-content/uploads/2015/06/73.-Caregiver-Presence-and-Patient-Completion-of-a-Transitional-Care-Intervention.pdf

24. Dahl U, Johnsen R, Saetre R, Steinsbekk A. The influence of na intermediate care hospital on health care utilization among elderly patientsare retrospective comparative cohort study. BMC Health Serv Res [Internet]. 2015 [cited 2017 May 04];15(1):1. Available from: https://www. ncbi.nlm.nih.gov/pmc/articles/PMC4323014/ 